\title{
Focus on the exploitation of Shale Gas in China and America
}

\author{
Shuangying Zhang ${ }^{1, a}$, Song Ju ${ }^{1, b}$ and Jin $\operatorname{Pan}^{1, c}$ \\ ${ }^{1}$ State Grid Liaoning electric power co., LTD., economic and technical research institute, Shenyang, \\ 110015, China.

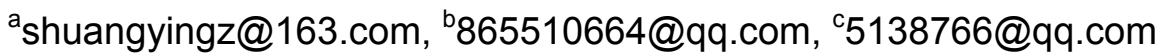

Keywords: shale gas, resource assessment, market trend.

\begin{abstract}
The shale gas revolution in America is considered as the most significant energy innovation in the 21st century, which has changed the pattern of American energy supply. While in China, the shale gas development has just begun. It is necessary to make a comparison between America and China, based on the respective development status of shale gas. The comparison can provide more objective evaluation for the exploitation of shale gas in China. The paper mainly analyzed the resource assessment and exploitation of Shale gas in China and America, and provided some suggestion for the development of shale gas in China.
\end{abstract}

\section{Introduction}

In 1980s, America began to explore shale gas. With the breakthrough of hydraulic fracturing and horizontal drilling, the output of shale gas grew rapidly. In 2011, the shale gas production in America was up to $1800 \times 108 \mathrm{~m} 3$, accounting for $27 \%$ of natural gas market. By 2035 , it is predicted the shale gas would account for about half of total natural gas production in America. The development of shale gas in China has just begun, but it is important for China to achieve the security and diversify energy supply. Besides, it is also an efficient way for China to transform to clean energy economy.

In recent years, many scholars researched the development of shale gas form different perspectives. Juan Roberto et al. regarded United States experience as a reference for shale gas development [1]. Tian Lei et al. used the US experience to shed light on how China overcomes the innovation problem inherent in exploring shale gas [2]. In the aspect of resource assessment, Christophe McGlade et al. pointed out that some substantial difficulties in assessing the resource potential of shale gas should be treated with caution [3]. J.D. Williams-Kovacs presented a new tool for shale gas exploration and development [4]. Shiping Liu, and Jinhua Zhang et al. summarized the evaluation methods of shale gas at home and abroad [5,6]. Jianzhong Li et al. studied the difference of accumulation conditions and distribution characteristics of shale gas between China and America [7]. Caineng Zou et al analyzed the formation, geological features and resources potential, and elaborated the characteristics of China's shale gas [8]. Jinchuan Zhang et al. analyzed enrichment type of China's shale gas and its features, and pointed that China has the same resource prospect and exploring potential as America [9]. Based on this, the paper mainly highlighted the resource potential of shale gas in China and America, and compared the resource characteristics and difficulties of exploration.

\section{Resource Assessment}

Resource potential and distribution. The shale gas of America is rich, with the resource potential up to $141.6-169.9 \times 1012 \mathrm{~m}^{3}$. As predicted by EIA, the mineable resource potential of shale gas in America is up to $24.41 \times 1012 \mathrm{~m}^{3}$. In China, MLR organized a nationwide survey on the Mainland's shale gas resource potential in 2011, and they preliminarily evaluated the resource potential of shale gas in the whole national land. Excluding the Qinghai Tibet, the geological resource potential of shale gas is up to $134.42 \times 1012 \mathrm{~m}^{3}$ in China, and the mineral resource potential is $25.08 \times 1012 \mathrm{~m}^{3}$. The resource potential of China's shale gas can be comparable with that of America. 
Both of the two countries have huge potentials and broad prospects for shale gas exploration and development.

In America, there are 48 states rich in shale gas resource. The resources are mainly distributed in northeast region, Gulf of Mexico, Southwest region, Mid-Continent region and Rocky Mountain, and there are 22 shale gas blocks in the five major regions. These shale gas blocks are clustered together in Northeast region (31.82\%) and Rocky Mountain (27.27\%). In the other three regions of America, the blocks are fairly fewer. In China, the resources are mainly distributed in four regions: Upper Yangtze and Dian-Qian-Gui Area, north and northeast China, Mid-lower Yangtze and southeast China, and northwest China. MLR carried out the Survey of National Shale Gas Potential Evaluation and favorable Areas Selected Project. According to the results of this project, there are more preferably favorable areas distributed in Upper Yangtze, Dian-Qian-Gui Area and North and Northeast China, accounting for $33.33 \%$ and $31.67 \%$ respectively. The following is Mid-lower Yangtze and Southeast China region, which accounts for $21.11 \%$ of the total number of areas. In the northwest China, the ratio of favorable areas is small, only $13.89 \%$.

The distribution of shale gas in the two countries is different. In America, the main production areas and prospective areas of shale gas are mainly distributed in the southern, central and eastern part of the United States, and the distribution is continuous and fairly concentrated. However in China, more resources are distributed in southern, northern and northwest areas of China, and the distribution are vast and scattered. It is hard for China to adopt the exploration technology of the United States.

Resource characteristics. The accumulation conditions of shale gas are important factors to measure the shale gas quality. There is no evaluation standard to evaluate the shale gas quality, but we can conclude the relative quality of China's shale gas by comparing with America. As shown in Table 1. The general geological structure of shale gas in America is simple, having undergone once lift and with less breakage. While in China, the geological structure of shale gas is complex, having undergone multiple reformations. As for the sediment types, the America's shale are single and mostly marine faces, and China's shale can be divided into three types: marine faces, continental faces and transitional faces. In America, the Total Organic Carbon (TOC) of shale blocks varies from $5 \%$ to $10 \%$, which is richer and higher than that of China. In China, the thermal maturity of shale has more changes than that of America. In terms of the gas content, it is higher in America than in China. Compared to America, the quality of China's shale gas is a little bit worse.

Table 1 The characteristics of shale in America and China

\begin{tabular}{|c|c|c|}
\hline & America & China \\
\hline $\begin{array}{l}\text { Geological } \\
\text { structure }\end{array}$ & Simple, once lift, less breakage & $\begin{array}{l}\text { Complex, multiple reformations, faults } \\
\text { developed }\end{array}$ \\
\hline Sediment types & Single, marine shale as the main & $\begin{array}{l}\text { Three categories, less marine faces, } \\
\text { more continental faces }\end{array}$ \\
\hline TOC & Rich, mainly $5 \%$ to $10 \%$ & Medium preference, mainly $1 \%$ to $5 \%$ \\
\hline Thermal maturity & $\begin{array}{l}\text { The Ro is moderate }(1.1 \%-2.0 \%) \text {, commonly } \\
\text { for gas peak stage }\end{array}$ & $\begin{array}{l}\text { The Ro have more changes, marine } \\
\text { higher }(\text { Ro }>2 \%) \text {, continental lower } \\
(\mathrm{Ro}<1.3 \%)\end{array}$ \\
\hline Gas content & High (average $\left.3-6 \mathrm{~m}^{3} / \mathrm{t}\right)$ & Low (on average $1-3 \mathrm{~m}^{3} / \mathrm{t}$ ) \\
\hline
\end{tabular}

The main chemical composition of shale gas is another important basis to measure the quality of shale gas. Generally speaking, the typical composition of shale gas is alkane, composed of vast majority of methane (70-90\%), a small quantity of ethane, propane and butane (totally $0-20 \%$ ). In addition, it contains hydrogen sulphide (0-5\%), carbon dioxide (0-8\%), nitrogen $(0-5 \%)$, oxygen $(0-0.2 \%)$, water and trace amounts of inert gas, such as helium and argon.

The shale gas of different shale blocks has different chemical composition. The paper selected many shale gas samples of the two countries and made a comparison (See Table 2). In the America's samples, the alkane accounts for $94.6 \%$ and non-flammable gas accounts for just $5.4 \%$. While in China's sample of Longmaxi, the alkane accounts for $86.9 \%$, the ratio of non-flammable gas 
especially nitrogen is higher. According to the main chemical composition, the quality of China's sample is fairly poorer.

Table 2 The components of America's sample and China's sample

\begin{tabular}{l|l|l|l}
\hline Components & America's sample & China's sample & Typical sample \\
\hline Methane & $88.40 \%$ & $86.50 \%$ & $70-90 \%$ \\
\hline Ethane & $5.00 \%$ & $0.16 \%$ & \multirow{2}{*}{$0-20 \%$} \\
\hline Propane & $1.20 \%$ & $0.04 \%$ & \\
\hline Butane & - & - & $0-5 \%$ \\
\hline $\mathrm{N} 2$ & $3.50 \%$ & $7.64 \%$ & $0-8 \%$ \\
\hline $\mathrm{CO} 2$ & $1.90 \%$ & $4.86 \%$ & $0-5 \%$ \\
\hline $\mathrm{H}_{2} \mathrm{~S}$ & - & - & $0-0.2 \%$ \\
\hline $\mathrm{O} 2$ & - & $0.36 \%$ & - \\
\hline $\mathrm{H} 2$ & - & $0.20 \%$ & - \\
\hline Alkane & - & $0.24 \%$ & - \\
\hline Balance & - & &
\end{tabular}

\section{Difficulty of exploitation}

Many reasons influence on the commercial production of shale gas, such as terrain, water resource and burial depth. The complex topography, scarce water resource and deep buried depth can increase the difficulties of shale-gas drilling. In America, $84 \%$ of shale gas reservoirs are in the flat terrain, with just a little part in mountainous west. While in China, the terrain appears a ladder-like distribution, descending from west to east. The north and northeast China have $27 \%$ of shale gas resources. The Mid-lower Yangtze and southeast China have 18\% of shale gas resources, with plains and hills as its main factors.

Hydraulic fracturing has been used to explore the shale gas, but it needs large amount of water. In America, the distribution of shale gas and water resources is harmonious, and the major shale blocks are mostly distributed in the plains where the Great Lakes, Mississippi River and Gulf of Mexico are located. Besides, the precipitation is also balanced with the distribution of shale gas in America, the Northeast region and Gulf of Mexico has $76 \%$ of shale gas reservoirs, and the precipitation is higher than 30 inches per year. While in China, the distribution of shale gas and water resources is unbalanced. Most of the potential areas are located in Drought Ordos Basin and Turpan-Hami Basin, where the season is dry. What's more, most shale blocks have seasonal water shortages. Five provinces (Sichuan, Chongqing, Guizhou, Yunnan and Guangxi) with $40 \%$ of China's shale gas reserves suffered a severe six-month drought in 2010. The North and Northeast of China have $26 \%$ of shale gas resources, but water is short. Lower Yangtze and the South-East of China with more abundant water resource only have $18 \%$ shale gas reserves. Moreover, the precipitation is also out of accordance with the distribution of shale gas.

Table 3 The burial depth comparison of the shale gas in America and China

\begin{tabular}{llll}
\hline & America & & China \\
\hline Area & Depth $(\mathrm{m})$ & Area & Depth $(\mathrm{m})$ \\
Antrim & $180-700$ & Songliao Basin & $300-1000$ \\
Fayetteville & $365.76-2286$ & Ordos Basin & $0-1000$ \\
Haynesville & $3048-3962.4$ & Sichuan Qiongzhusi & $2600-4600$ \\
Marcellus & $1524.0-2438.4$ & Sichuan Longmaxi & $1600-4200$ \\
Eagle ford & $600-4500$ & Tarim Basin & $2000-8000$ \\
Woodford & $1500-4500$ & Yangtze Area & $2000-4000$ \\
Barnett & $1645.9-2926.08$ & Qaidam Basin & $>2000$ \\
\hline
\end{tabular}

Besides the terrain and water source, the burial depth is another important factor affecting developing shale gas. The burial depth of shale gas is deeper, the exploitation of shale gas is more difficult. The shale gas reservoirs in America have large areas of continuous distribution, and its burial depth is moderate $(1000 \mathrm{~m}$ and $3500 \mathrm{~m})$. While in China, the burial depth was mainly between $2000 \mathrm{~m}$ and $4000 \mathrm{~m}$. Over half of shale gas reservoirs is in the south, and the burial depths is more than 
$3000 \mathrm{~m}$, some even greater than $5000 \mathrm{~m}$ ( See Table 3). In additation, there are some other reasons would limit the development, such as the pipelines and infrastructures. The pipe networks are highly developed in America, up to $550,000 \mathrm{~km}$. In China, by contrast, the pipe networks is underdeveloped, It is only cover approximately $40000 \mathrm{~km}$. Most of shale blocks in central and western mountainous regions, and it is difficult and costly to carry out the construction of shale gas pipelines.

By contrasting these assessment results, the paper find that China's shale gas is deeper and more miscellaneous compared with America's shale gas. On the whole, China has huge reserves of shale gas, but the characteristics are poorer.

\section{Conclusion}

By studying the resource assessments of shale gas in America and China, it is easy to draw the conclusion that both of the two countries have broad prospects for shale gas exploration. Firstly, the distribution of shale gas in both countries is different. In America, it is relatively concentrated, while in China, it's scattered. Besides, shale gas in two countries has different composition. Secondly, America's shale gas industry will usher in a golden age of rapid development, while in China, and the shale gas industry is only at the beginning stage with a rapid growth rate. Finally, the American government has passed a series of incentive policies to encourage shale gas exploration, which can provide an excellent example for China's practices.

\section{Acknowledgements}

The research work was supported by "Science and technology project funding by State Grid Liaoning electric power co., LTD” (Grant No.5222JJ14001F).

\section{References}

[1] Juan Roberto, Lozano Maya, The United States experience as a reference of success for shale gas development: The case of Mexico, J. Energy Policy. 62 (2013) 70-78.

[2] Tian Lei, Zhongmin Wang et al. Stimulating shale gas development in China: A comparison with the US experience, J. Energy Policy. 75 (2014) 109-116.

[3] Christophe McGlade, Jamie Speirs, Steve Sorrell, Methods of estimating shale gas resources e Comparison, evaluation and implications, J. Energy. 59 (2013) 116-125.

[4] J.D. Williams-Kovacs, C.R. Clarkson, A new tool for prospect evaluation in shale gas reservoirs, J. Journal of Natural Gas Science and Engineering. 18 (2014) 90-103.

[5] Shiping Liu, Reviews on shale gas resource evaluation method, J. Jianghan Petroleum Science and Technology. 23 (2013) 30-35.

[6] Jinhua Zhang, Wei Wei, Taixian Zhong, Evaluation Methods Analysis about Resources and Reserves of Foreign Shale Gas, J. SINO-GLOBAL ENERGY. 16 (2011) 38-42.

[7] Jianzhong Li, Denghua Li et al. Comparison and enlightenment on formation condition and distribution characteristics of shale gas between China and U.S, J. Engineering Science. 6 (2012) 56-62.

[8] Caineng Zou, Dazhong Dong, Geological characteristics, formation mechanism and resource potential of shale gas in China, J. Petroleum Exploration and Development. 37 (2010) 641-653.

[9] Jinchuan Zhang, Shengling Jiang, Accumulation types and resources characteristics of shale gas in China, J. Natural Gas Industry. 29(2009) 109-114. 